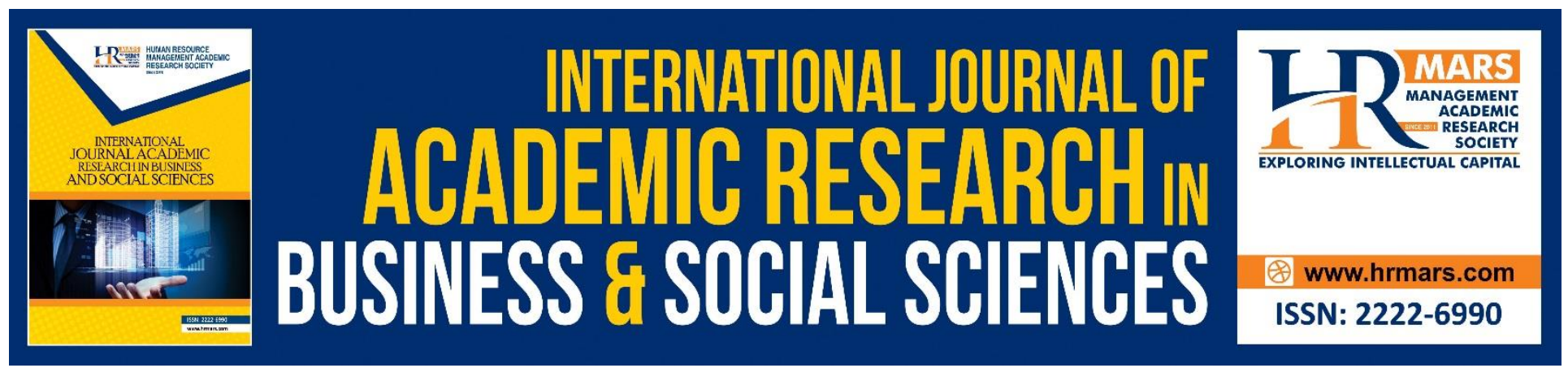

\title{
Critical Success Factors of Perak Youth Business Planning System (SRPBP)
}

Nurul Fadly Habidin, Mad Ithnin Salleh, Nor Azrin Md Latip, Sharon Yong Yee Ong and Nursyazwani Mohd Fuzi

To Link this Article: http://dx.doi.org/10.6007/IJARBSS/v8-i9/4857

DOI: $\quad 10.6007 /$ IJARBSS/v8-i9/4857

Received: 17 August 2018, Revised: 19 Sept 2018, Accepted: 29 Sept 2018

Published Online: 05 October 2018

In-Text Citation: (Habidin, Salleh, Latip, Ong, \& Fuzi, 2018)

To Cite this Article: Habidin, N. F., Salleh, M. I., Latip, N. A. M., Ong, S. Y. Y., \& Fuzi, N. M. (2018). Critical Success Factors of Perak Youth Business Planning System (SRPBP). International Journal of Academic Research in Business and Social Sciences, 8(9), 1473-1481.

Copyright: (C) 2018 The Author(s)

Published by Human Resource Management Academic Research Society (www.hrmars.com)

This article is published under the Creative Commons Attribution (CC BY 4.0) license. Anyone may reproduce, distribute, translate and create derivative works of this article (for both commercial and non-commercial purposes), subject to full attribution to the original publication and authors. The full terms of this license may be seen

at: http://creativecommons.org/licences/by/4.0/legalcode

Vol. 8, No. 9, September 2018, Pg. 1473 - 1481

Full Terms \& Conditions of access and use can be found at http://hrmars.com/index.php/pages/detail/publication-ethics 


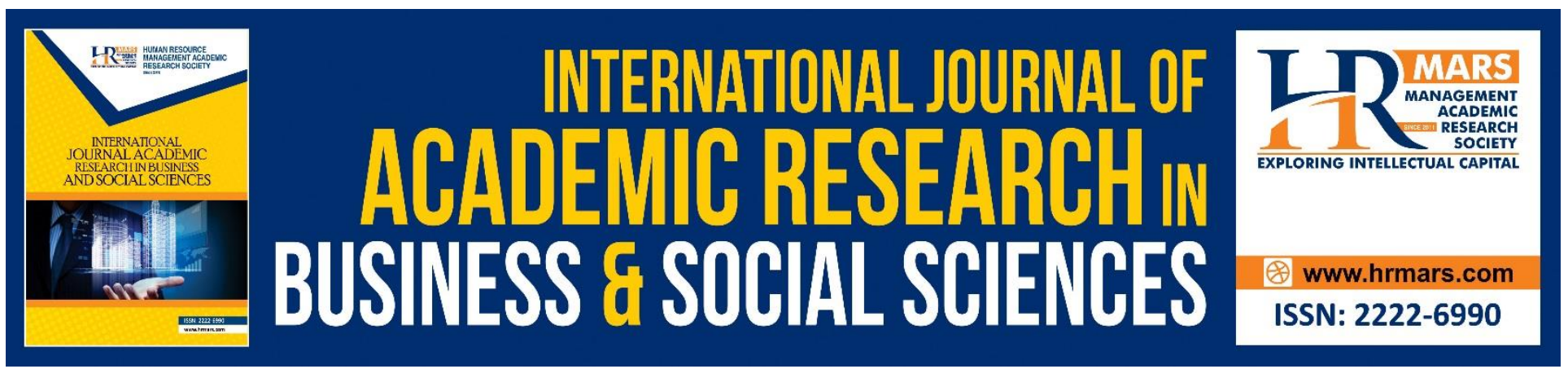

\title{
Critical Success Factors of Perak Youth Business Planning System (SRPBP)
}

\author{
Nurul Fadly Habidin*1, Mad Ithnin Salleh², Nor Azrin Md Latip ${ }^{3}$, \\ Sharon Yong Yee Ong ${ }^{4}$ and Nursyazwani Mohd Fuzi ${ }^{5}$ \\ *1, 2, 3, 4 Department of Management and Leadership, Faculty of Management and Economics \\ Universiti Pendidikan Sultan Idris, Tanjong Malim, Perak, Malaysia \\ ${ }^{5}$ Department of Accounting and Finance
}

Faculty of Management and Economics, Universiti Pendidikan Sultan Idris Tanjong Malim, Perak, Malaysia

\begin{abstract}
Business Plan is a formal business document and evidence of youth entrepreneurship initiatives to deliver business-to-business business plans step by step to achieve business goals. The business plan represents an important tool with a positive impact on the survival opportunities of youth entrepreneurs business. The key factors that are usually included in most business plans and these factors will be developed in the Perak Youth Business Planning System (SRPBP). The conceptual framework developed for this study was drawn from various literature review perspectives, the propose factors, namely business profile, administrative management, marketing management, operational management and financial management. The business plan produces by using SRPBP system help youth entrepreneur to get loans and investments from financial institutions and to collaborate with other companies. Thus, it enables youth entrepreneurs to use the systems developed in this study to generate business plans.
\end{abstract}

Keywords: Factor, Business Plan, Business Plan Systems, Youth Entrepreneurs

\section{Introduction}

The number of youth entrepreneurs is one of the issues that are often discussed in the national economic development agenda (Khana, Noorb \& Anuarb, 2016). Youths are a great source of potential and can contribute substantially to national development. The ability to capitalize on their potential will help determine Malaysia's strength and resilience in social, economic and political development.

In Malaysia, the age of youth is defined as between 15 and 30 years but the main focus of development programs in this country is for those between the ages of 18 to 30 years. According to 
INTERNATIONAL JOURNAL OF ACADEMIC RESEARCH IN BUSINESS AND SOCIAL SCIENCES Vol. 8, No. 9, Sept. 2018, E-ISSN: 2222-6990 @ 2018 HRMARS

the Malaysian Youth Research Institute (IYRS), in 2014 the Malaysian Youth population aged 15 to 30 years was 9.1 million representing 30 percent of the population. Thus, youths are a great source of potential that can be extended by developing youth entrepreneurs.

The Malaysian government encourages graduates to become entrepreneurs after graduating (Mohamed, Rezai, Nasir Shamsudin \& Mu'az Mahmud, 2012) and it is considered as a good opportunity for Malaysian youths. This recognition can be seen through various mechanisms and support policies initiated by the government to encourage the youth to participate in entrepreneurship. According to a report by SME Corporation Malaysia (2017) one of the nation's top priority development strategies and emphasis is the development of entrepreneurship among youths that will shape the generation of youths who have corporate leadership. This strategy is supported by the National Youths Policy aimed at empowering youth to fulfill their potential through entrepreneurship, education and training skills, as well as sports and volunteerism; to facilitate the realization of Initiative Countries and the 2050's transformation agenda (TN50). Among the programs that have been implemented are talent corp program, "Sme-University Internship" program, Bumiputera Youth Entrepreneurship Program (TUBE) and others.

Khana, Noorb, and Anuarb (2016) studies have suggested that despite many government support and assistance in terms of grants, funding, provision of training and consulting services, but many youthoperated businesses still fail and rates of failure are still high. As reported by the Central Bank of Malaysia (2016) the average amount of bankruptcy among companies in Malaysia from 1998 to 2015 is 1,250 companies. Thus, there are 107,306 bankruptcy cases among Malaysian entrepreneurs between January and April 2015, of which 948 are youth (The Star Online, 2015). This proves that the rate of youth subsidies to become entrepreneurs in Malaysia is still low, and does not reach the target.

Recent studies have also found that many young entrepreneurs can only be active in a short period of time because of the lack of capacity to manage business resources is one of the factors that prevent the efforts of ethnic groups in entrepreneurial growth (Sefiani, 2013; Zimmerman \& Chu, 2013; Ghazali, 2014; Ridzwan, Muhammad, \& Ab Rahman, 2017). To assist youth in managing business resources, business plans are essential to ensure youth development in entrepreneurship (Ishak, Omar, \& Ahmad, 2012). Hence, this study will identify factor of business plan to help entrepreneurs build business plans and further develop software to produce business plans.

\section{LITERATURE REVIEW}

This section will highlight the literature review of important studies relevant to Business plan and critical success factors contribute to Business Plan Systems.

\section{Business Plan}

Business Plan is a formal business document and evidence of youth entrepreneurship initiatives to deliver business-to-business business plans step by step to achieve business goals. It enables youth entrepreneurs to create objectives, critical views, evaluate competition and set competitive 
INTERNATIONAL JOURNAL OF ACADEMIC RESEARCH IN BUSINESS AND SOCIAL SCIENCES Vol. 8, No. 9, Sept. 2018, E-ISSN: 2222-6990 @ 2018 HRMARS

alternatives and business advantages and help identify solutions for possible problems (Liu \& Hsu, 2011; Haag, 2013). The business plan represents an important tool with a positive impact on the survival opportunities of youth entrepreneurs business.

The study by Simón-Moya and Revuelto-Taboada (2016) states that one of the more frequently used forms of institutions in evaluating entrepreneurship applications is through business plans. In Malaysia, various assistance programs have been provided specifically for youth entrepreneurs. However, existing financial institutions and programs mostly require business plans to assess the potential of entrepreneurs (Haag, 2013; Simón-Moya \& Revuelto-Taboada, 2016; SME Corporation Malaysia, 2017) to ensure that the proposed business is tailored to the program and the applicant repay the loan. Hence, the preparation of business plans should be clear and concise.

As new business numbers increase each year, competition for financing is increasing. Youth entrepreneurs who provide business plans with clear business profiles, business resource management capabilities, marketing capabilities, operational management and financial management have a competitive advantage and are more successful in securing the necessary financing and loans (Haag, 2013). However, the advantage of a business plan is not just to get funding or lending from institutions, youth entrepreneurs also benefit from business planning to achieve business goals.

\section{Critical Success Factors in the Perak Youth Business Planning System (SRPBP)}

In the next section, the components of the business plan listed below are the key factors that are usually included in most business plans and these factors will be developed in the Perak Youth Business Planning System (SRPBP).

\section{Business Profile}

The objectives of this factor are in the SRPBP system to illustrate the business, the type of business and the form of products or services offered. Business profile provides business brief information. If the new business, the following questions should be answered (Bangs, 1995):

1. What is a valid business name?

2. What type of business is selected?

3. Where is the business located?

4. What are the business products and services?

In addition to the listed, date of registration, no. telephone, fax, email, bank account information, social media information such as Facebook, Instagram, Twitter and others, business startup capital, company achievement, company background listing and business plan objectives are included. Business Name requires legal name searches to prevent copyright issues and others. Business names should be easy to remember, spell and enter information about what entrepreneurs do. The name of the business name needs to be considered because the name is the first prospect of identification. Information on business backgrounds should be provided to support any loan or loan demand. The 
INTERNATIONAL JOURNAL OF ACADEMIC RESEARCH IN BUSINESS AND SOCIAL SCIENCES

Vol. 8, No. 9, Sept. 2018, E-ISSN: 2222-6990 (C) 2018 HRMARS

legal type of business is listed (that is, sole proprietorship, partnership, corporation, and limited liability company).

\section{Administrative Management}

Various studies analyzing key factors in SMEs, Haag (2013) noted that 98\% of failure occurred from management weaknesses. The majority of these factors do not involve the lack of knowledge on business products or services. On the other hand, it relates to administrative and business operations (Lasher, 2010). When preparing administrative management, three things need to be explained (Bangs, 1995; Lasher, 2010; Ciaburri, Napolitano, \& Bravo, 2017):

1. Personal history of entrepreneurs (Academics, courses attended to)

2. Duties and responsibilities

3. Salary

Personal history of entrepreneurs, education, courses attended, and personal financial status. Entrepreneurial experience such as courses previously attended explaining entrepreneurs have experience directly related to business and have the necessary skills. This is because, related institutions want to provide funding or loans to individuals (youth entrepreneurs), not to companies (Haag, 2013). This Management factor is important in convincing decision makers that this business administration is serious and has the intention to focus on business ventures and able to repay the loan or potentially grow. In addition, Vision, Mission and business objectives are also proposed by past studies as most business premises do not have the mission statement and vision of the company (Abdullah \& Mustapha, 2009).

\section{Marketing Management}

The marketing management factor explains the existing market where entrepreneurs introduce the marketing strategy of the company. According to Bangs (1995) and Darling (2015), Customers are the key focus in marketing management and it is important to ensure entrepreneurs achieve business performance. Marketing plans and strategies need to clarify the following (Haag, 2013; McKeever, 2016; Ciaburri et al., 2017):

1. SWOT analysis

2. Market trends

3. Customer target

4. Marketing methods

At its most basic level, the marketing strategy uses the SWOT (Strength, Weakness, Opportunitiy, and Threat) analysis (Darling, 2015; Bohari, Hin, \& Fuad, 2017). This analysis describes strengths, weaknesses, opportunities and business threats to help explain how threats or problems are addressed. These elements are listed in the SRPBP system to help entrepreneurs document their marketing strategies. In addition, market share, current annual forecasts and marketing strategies are also important in marketing management (Lasher, 2010). These elements help youth 
INTERNATIONAL JOURNAL OF ACADEMIC RESEARCH IN BUSINESS AND SOCIAL SCIENCES

Vol. 8, No. 9, Sept. 2018, E-ISSN: 2222-6990 (C) 2018 HRMARS

entrepreneurs determine their competitors and their pricing policies, promotion strategies, and relative market share.

\section{Operational Management}

Management of business plan operations describes the functioning of daily business activities. This section differs depending on the type of business that youth entrepreneurs want to venture into. According to Habidin et al. (2014), the elements included in the management of operations are:

1. Process flow chart (productivity, fabrication, assemblies, inspection tests, inventory control).

2. Location

3. Labor

4. Manufacturing capacity (equipment, materials, staff, space).

5. Operating costs

The elements mentioned above are also listed in the SRPBP system to facilitate youth entrepreneurs formulate business operations management. Haag (2013) suggests in the business plan of the operating section not to be detailed. Instead, it should be concise and accurate. This is because readers may lack technical knowledge to understand the process.

\section{Financial Management}

Financial management and analysis are important in business plans to clarify the management, financial structure and potential of the business to grow (Ciaburri et al., 2017). In this study, financial management factors focus on the business plan of a youth entrepreneur who wants to start a business. The study by Abubakar (2015) shows that entrepreneurs experiencing problems in planning and managing finances face constraints on entrepreneurship development, especially in SMEs. It is therefore important to produce a complete financial plan in the business plan. According to Lasher (2010) and Haag (2013), financial management in a business plan contains a set of financial plans, including:

1. Income statement

2. Balance sheet

The reports mentioned above are standard for most businesses. In the SRPBP system, the framework for the report has been provided and entrepreneurs only need to fill out the statement. This helps entrepreneurs prepare and understand business finance. Abubakar (2015) states that entrepreneurs need to understand how each of these documents is developed and should learn about financial statements. Functions in the SRPBP system allow filling and changes in the preparation of finance portfolios.

\section{Development of the Perak Youth Business Plan System (SRPBP)}

There are many sections that need to be covered in business plans and many sections that are easily dropped by entrepreneurs during the process of providing the document (MaRS, 2009). Silver Youth 
INTERNATIONAL JOURNAL OF ACADEMIC RESEARCH IN BUSINESS AND SOCIAL SCIENCES Vol. 8, No. 9, Sept. 2018, E-ISSN: 2222-6990 @ 2018 HRMARS

Business Plan (SRPBP) system is developed based on 5 factors namely business profile, administrative management, marketing management, operational management and financial management. The SRPBP System interface is intuitive and easy to use, it provides a framework for preparing business plans more easily, concisely and practically. Most content for the stated factors has been provided in the SRPBP system. Youth entrepreneurs only choose existing content, identify business focus and fill out other business-related information. This system can also be used as a guide line to help youth entrepreneurs coordinate and process business plans

\section{Method}

The purpose of this study is to examine the factors contained in the SRPBP to assist the youth of Perak to produce a complete business plan. The development of questionnaires in this study is in line with the key factors in the business plan. These factors will be analyzed to be developed in the SRPBP system. In the early stages, key elements will be identified and used to develop SRPBP systems. In the second stage, the SRPBP System will be introduced through a business plan workshop. The students who take the course of this business plan will be the sample of this study. The sample of this study is expected to involve 200 youths around Tanjong Malim, Perak. Focusing on the second stage is to identify the factors in the SRPBP system and to develop the SRPBP system to help the user set up a complete business plan. The instrument to be used is a questionnaire. All respondents' responses were analyzed using the Statistical Package for Social Science (SPSS) Version 21.0 software. Descriptive analysis will be used to get the results of the study. This SRPBP system will be developed using Adobe Dreamweaver, SQL and Web Based software. The conceptual framework developed for this study was drawn from various literature review perspectives (Lasher, 2010; Haag, 2013; Habidin et al., 2014; Abubakar, 2015; Ciaburri et al., 2017), the propose factors, namely business profile, administrative management, marketing management, operational management and financial management as shown in Figure 1.

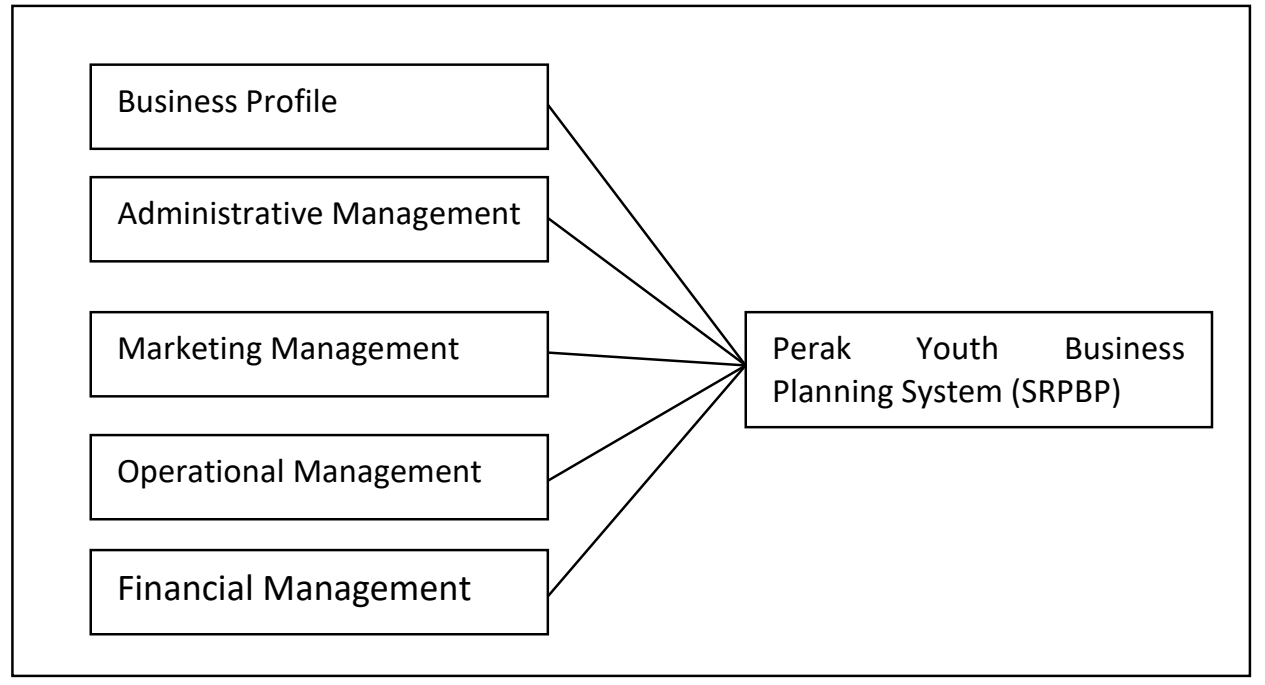

Figure 1. Factor-factors in the Perak Youth Business Planning System (SRPBP)

Figure 1. present the illustrative presentation of the variables presented in the Perak Youth Business Planning System (SRPBP). Five variables or factors will be included in the system development. 
INTERNATIONAL JOURNAL OF ACADEMIC RESEARCH IN BUSINESS AND SOCIAL SCIENCES

Vol. 8, No. 9, Sept. 2018, E-ISSN: 2222-6990 @ 2018 HRMARS

\section{Conclusion}

This paper proposed the development of Business Planning System (SRPBP). The literature reveals the importance of business plans, the factors that contained in the business plan and the development of Perak Youth Business Planning System (SRPBP). Factors contained in business plans have been explored in various perspectives and the literature on SRPBP development has also been studied. The results of this study give importance to youth entrepreneurs in terms of develop business plan especially for youth entrepreneur that face difficulties in writing business plan. The system is expected to help youth prepared business plan that strengthen the company profile and act as business guideline. The business plan produces by using SRPBP system help youth entrepreneur to get loans and investments from financial institutions and to collaborate with other companies. Thus, it enables youth entrepreneurs to use the systems developed in this study to generate business plans.

\section{Corresponding Author}

Nurul Fadly Habidin

Department of Management and Leadership

Faculty of Management and Economics

Universiti Pendidikan Sultan Idris

35900 Tanjong Malim, Perak, Malaysia

Email: fadly@fpe.upsi.edu.my

\section{References}

Abubakar, H. A. (2015). Entrepreneurship development and financial literacy in Africa. World Journal of Entrepreneurship, Management and Sustainable Development, 11(4), 281-294.

Bangs, D. H. (1995). Business Planning Guide-Creating Practical Plans for Your Start-up Ven-ture's Success. Chicago, IL: Upstart Publishing

Bohari, A. M., Hin, C. W., \& Fuad, N. (2017). The competitiveness of halal food industry in Malaysia: A SWOT-ICT analysis. Geografia-Malaysian Journal of Society and Space, 9(1).

Ciaburri, M., Napolitano, M., \& Bravo, E. (2017). Business planning in biobanking: How to implement a tool for sustainability. Biopreservation and biobanking, 15(1), 46-56.

Darling, R. M. (2015). Startups in Small Summer Tourism Markets: Maintaining Stability in the Slower Winter Months(Doctoral dissertation).

Haag, A. B. (2013). Writing a successful business plan: An overview. Workplace health \& safety, 61(1), 19-29.

Habidin, N. F., Soter, M. S. A., Zainudin, M. Z., Roslan, M. H., Norazlan, A. N. I., \& Aualudin, M. F. (2014). Applikasi Pelan Rancangan Perniagaan BEPA. Tanjong Malim, Perak: Pusat pembangunan keusahawanan UPSI.

Ishak, S., Omar, A. R. C., \& Ahmad, A. (2012). Tales of the Survivors: The Bumiputera Entrepreneurs' Experience. Asian Social Science, 8(3), 25.

Khana, S. J. M., Noorb, N. S. M., \& Anuarb, A. R. (2016). Performance among Youth Entrepreneur in Malaysia Micro SMEs in The European Proceedings of Social \& Behavioral Sciences, 621-627. Doi:10.15405/epsbs.2016.08.88 
INTERNATIONAL JOURNAL OF ACADEMIC RESEARCH IN BUSINESS AND SOCIAL SCIENCES

Vol. 8, No. 9, Sept. 2018, E-ISSN: 2222-6990 (C) 2018 HRMARS

Lasher, W. (2010). The Perfect Business Plan Made Simple: The best guide to writing a plan that will secure financial backing for your business. New York, NY: Doubleday Dell

MaRS (2009). Building Block 2 The Business Plan and Executive Summary. Retrieved from http://www.marsdd.com/wp-content/uploads/2010/12/The-Business-Plan-ExecutiveSummary-WorkbookGuide.pdf

McKeever, M. (2016). How to write a business plan. Berkeley, CU: Nolo.

Mohamed, Z., Rezai, G., Nasir Shamsudin, M., \& Mu'az Mahmud, M. (2012). Enhancing young graduates' intention towards entrepreneurship development in Malaysia. Education+ Training, 54(7), 605-618.

Ridzwan, R., Muhammad, N. M. N., \& Ab Rahman, A. A. (2017) Issues and Challenges among Young Entrepreneurs in Malaysia. IOSR Journal of Business and Management, 19(3), 80-84.

Simón-Moya, V., \& Revuelto-Taboada, L. (2016). Revising the predictive capability of business plan quality for new firm survival using qualitative comparative analysis. Journal of Business Research, 69(4), 1351-1356.

SME Corporation Malaysia (2017). Chapter 5 SME and Entrepreneurship Development Programmes in $2017 . \quad$ Retrieved from http://www.smecorp.gov.my/images/SMEAR/Chapter_5_MegaTUBE.pdf

Zimmerman, M. A., \& Chu, H. M. (2013). Motivation, success, and problems of entrepreneurs in Venezuela. Journal of Management Policy and Practice, 14(2), 76-90. 